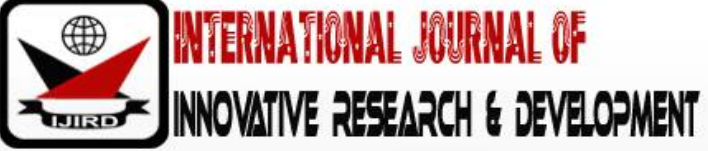

ISSN 2278 - 0211 (Online)

\section{The Determinants of Financial Inclusion for Competitiveness Improvement of SME's in East Java Province}

\author{
Dr. Haryati Setyorini \\ Lecturer, Department of Management, STIE Perbanas Surabaya, Indonesia \\ Dr. M. Nadjib Usman \\ Lecturer, Department of Management, STIE Perbanas Surabaya, Indonesia
}

\begin{abstract}
:
Financial inclusion is an effort to eliminate all forms of constraints with price and non-price characteristics on public access to use financial services. Financial inclusion is a national strategy to boost economic growth through equal income distribution, poverty reduction, and financial system stability. Financial inclusion is defined as the availability and equality of opportunities to access financial services. The elements of financial inclusions are financial literacy, access to financial services, saving habits, education, and government policy. Financial inclusion can also be defined as the use of formal accounts can bring many benefits to individuals. This paper explores the most dominant factor of financial inclusion that generates significant value for competitiveness improvement of Small Medium Enterprises (SME's), especially in East Java Province. Based on the data 2017, total SME's in East Java is 12.1 million units, but only 1.3 million readies for the competition and ready for collaboration in the digital era (Kompas, 19 October 2018). The method that used is multiple regression analysis using SPSS 24 statistics tools. The total respondent is 205 SME's owners that spreading all over East Java. Based on the validity and reliability test, all variables are valid and reliable(see table 7 and table 8). Based on multiple regression analysis - under stepwise method, we found that bank access has the most significant effect that other variables. The second step of the significant variable is education background and the third step is government regulation (see table 10). That means bank access, education and government regulation have a significant effect on competitiveness improvement of SME's in East Java Province. The recommendation from the researcher can be stated as follows: to the SME's owners, they must improve the knowledge through improving educational background to increase their competitiveness. To the banking institution, they shall improve their policy and regulation for giving easiness to the SME's on increasing their working capital. To the government, shall improve their policy orregulation that related to the improvement of the competitiveness of SME's.
\end{abstract}

Keywords: Financial literacy, bank access, saving habits, education, government policy, competitiveness

\section{Introduction}

Successful development is marked with the establishment of a stable and useful financial system for all people. In this instance, financial institutions play a vital role through their intermediary function to boost economic growth, equal income distribution, poverty reduction, and achievement of financial system stability. Unfortunately, the rapid developing of the financial industry is not always accompanied by adequate financial access. Meanwhile, financial service access is an important prerequisite for community involvement in the economic system.

The World Bank's Survey (2010) shows that only 49 percent of Indonesian households have access to formal financial institutions. Bank Indonesia revealed the same in a Household Balance Sheet Survey (2011) showing that 48 percent of households save their money with formal financial institutions and non-financial institutions. Therefore, $52 \%$ of people do not have any savings with banks or non-bank financial institutions. The two surveys mutually reinforce and support that the access of Indonesian people to formal and non-formal financial institutions is still relatively low, and therefore, the access of Indonesian people to the financial service system must be increased.

In economic development in Indonesia, banks play a vital role to function as the driver of financial inclusion activities because Indonesian banks have a financial activity share up to $80 \%$. However, financial inclusion involvement is related to not only the task of Bank Indonesia but also the Government in efforts to provide financial services to the wider community.

East Java Province, as the $2^{\text {nd }}$ larger Province in Indonesia, recently has 12.1 million units of SME's but only 1.3 millionunits ready to enter the competition in the globalization era. That means still need more efforts to boost SME's to improve their competitive advantage. According to National Strategy for a national development strategy to boost economic growth through equal income distribution, poverty reduction, and financial system stability through Financial Inclusion, it is expected the collaboration between government institutions and stakeholders may be created in a close and structuredmanner. Thus, this research will focus on analyzing the determinants of financial inclusion that effecton competitiveness improvement of SME's in East Java Province. 
This study attempt to investigate the financial inclusions element such as financial literacy, accessibility to the bank, saving habit, education background, government regulation that has the most significant effect on the competitiveness of the SME's especially in East Java Province. The resulting finding expected to give more benefit to the Government on the formulation of the regulation about an improvement of SME's sector to have a competitive advantage in the globalization era.

\section{Literature Review}

Financial inclusion (Bank Indonesia, 2014) is defined as the right of every individual to have access to a full range of quality financial services in a timely, convenient, informed manner and at an affordable cost in full respect of his/ her personal dignity. Financial services are provided to all segments of the society, with particular attention to low-income poor, productive poor, migrant workers and people living in remote areas.

Financial inclusion would mean providing every household with access to a suite of modern financial services, including savings, credit, insurance, and payments, as well as sufficient education and support to help customers make good decisions for themselves. These products and services must be affordable, designed to meet the population's needs, available within reasonable physical proximity, and regulated and overseen to protect consumers (Goland, 2010). The financial market plays a vital role in providing basic services in the modern economy, particularly in the processing of funds from surplus units to deficit units. Developed financial systems can help to promote economic growth (Levine, 2007).

Nowadays, financial inclusion becomes the key issue, but still, there is much progress to be made. Kumar (2013) revealed that an increase in banking networks has a positive impact on financial inclusion. Beck et al., (2007a, 2007b) found the increase in the number of bank branches will increase efficiency among the banks as well as a positive increase in growth rate. Financial inclusion is the way to utilize financial services at low cost and affordable to reduce informal accounts (Gwalani \& Parkhi, 2014). Chakravarty\& Pal (2013) developed an index to measure financial inclusion and found financial inclusion is robust for economic development in India.

Financial literacy is the possession of the set of skills and knowledge that allows an individual to make the informed and effective decision with all of their financial resources. About financial literacy in Indonesia based on a survey (Tempo, 4 October 2018), national literacy and financial inclusion poll show that the majority of the people only 29.7 percent out of 67.8 percent respondents that use financial products and services and complete understanding of financial product and services.

Access to the financial services, that means the availability of access for society. It aims to build the public capacity, primarily those categorized not eligible to become eligible or unbankable to become bankable by normal financial institutions, particularly productive poor people and micro and small businesses. Initiatives made in this pillar include a) capacity building (through training and technical assistance), b) alternative of guarantee system (simpler but still considering their relevant risks), c) provision of simpler credit services, d) identification of potential customers.

Saving is the essential instrument for capital accumulation and formation which further enhance economic growth and development through investing the saved fund. This research will explore more deeply how SME's especially SME's in East Java has a saving habit. Through this indicator would give a clear description of SME's and easier for the government to give the solution how to develop or to increase the capability and capacity of SME's to have global competitiveness.

The next determinant that will be evaluated is the education background of SME's owners or management. The education background of the owners or management will describe how far their plan and efforts to develop their business or SME's.

Government policy or government regulation is one of the variables that affect the development of SME's. The government has issued new regulation for SME's on payment of taxes, is PP No. 23/2018. Under these rules actually, SME's has given an incentive from the government to generate the highest profit with taxes is very low only $0.5 \%$.

\subsection{Hypothesis}

\subsubsection{Financial Literacy}

Financial inclusion is the basic pillar of economic development and stability (Rao, 2012). Financial inclusion is the key success of developing economic growth. Financial inclusion measures the delivery and reaches of banking services at reasonable cost to the vast sections of low income and disadvantaged groups. Strong inclusive financial systems allow people with limited funds, access to invest in their education and small entrepreneurs chance to pursue promising growth opportunities, thus promoting income equality and higher economic growth. One of the determinants of financial inclusion is financial literacy.

Lower levels of financial literacy play a pivotal role that prevents individuals from making use of formal financial services. Cole et al. (2011) documents that financial literacy matters in ameliorating understanding of financial products for uneducated and financially illiterate households and hence, the likelihood of opening formal saving accounts for such households tends to increase. (Beck et al., 2012; Sassi and Gasmi, 2014), notwithstanding the importance of access to formal savings, people's awareness of the role of access to credit also needs to acquire particular attention, because recent studies highlight that productive credit, but not consumption credit, is an important determinant of economic growth.

As the world becomes increasingly risky and globalized, financial literacy is critical to ensure that citizen could manage their budgets, invest wisely, and accumulate wealth. Thus, good financial literacy will encourage people to know how they can prepare their future both in life and in business. Based on that arguments the hypothesis that can develop is :

- H1 : Financial literacy has a significant effect on competitiveness improvement of SME's 


\subsubsection{Access to Financial Services}

The second determinant financial inclusion is access to financial services, that means financial inclusion measures the delivery and reach of banking services at reasonable cost to the vast sections of low income and disadvantaged groups. Strong inclusive financial systems allow people with limited funds, access to invest in their education and small entrepreneurs chance to pursue promising growth opportunities, thus promoting income equality and higher economic growth. This is the reason why even developed nations are concerned about those excluded from the financial system. Financial Inclusion aims at providing financial services to the vulnerable section of the society at an affordable cost.

Access to financial services varies widely across the globe. Demirguc-Kunt (2012) stated that even in some advanced countries; almost one in five adults has no bank account of the form the access to the formal financial sector. In many emerging and developing countries, the share of unbanked adults can be as high as $90 \%$, but with the inclusion is likely to keep expanding in the future, supported by economic development and initiatives by central bank and policymaker.

Financial inclusion handbook (2014), based on the World Bank's Survey (2010) shows that only 49 percent of Indonesian households have access to formal financial institutions. Bank Indonesia revealed the same in a Household Balance Sheet Survey (2011) showing that 48 percent of households save their money with formal financial institutions and non-financial institutions. Therefore, $52 \%$ of people do not have any savings with banks or non-bank financial institutions. The two surveys mutually reinforce and support that the access of Indonesian people to formal and nonformal financial institutions is still relatively low, and therefore, the access of Indonesian people to the financial service system must be increased. According to the arguments, the hypothesis that can be developed is:

- H2 : Access to Financial Services has a significant effect on competitiveness improvement of SME's.

\subsubsection{Saving Habits}

A habit has been viewed differently by various scholars. Habit is a regularly repeated behavior pattern: an action or pattern of behavior that is repeated so often that it becomes typical of somebody, although he or she may be unaware of it (Encarta, 2010). An individual's habit is, therefore, his/ her characteristic ways of thinking, feeling, and acting. Examples of habits are playing football, experiencing relaxation, saving money, solving business mathematics and so forth. Two major types of habits are easily deciphered namely overt (easily recognizable) and covert (hidden) habit; desirable (good) habit or undesirable (bad) habit; and weak or excess habit. Habit can be observed, recorded and measured.

Saving habits the behavior of the people to save and hold their money. It can be into the bank, as a deposit, to the stock market, buy jewelry, hold at home, or buy a property asset such as land, building. saved money and saving is one of the key qualities of a successful entrepreneur. Rimamnde., et.al.,(2015) while most people saved, not all such savings are geared towards investment and entrepreneurial development though there is a positive correlation between savings and entrepreneurial development. This research will focus on saving habits of the management of SME's. Therefore, the hypothesis that can develop is :

- H3 : Saving habits have a significant effect on competitiveness improvement of SME's

\subsection{Education}

Education as the next determinant of financial inclusion. Hilal (2015) investigate the effects of higher education on global competitiveness One of the most widely accepted definitions of global competitiveness is in the form of " efficiency level encompassing all of the institutions that will ensure sustainable growth in a country, policies, and factors of production". Therefore the competitiveness of a country depends on the factors such as; The level of development of R \& D activities and productivity, a performance of various sectors, the country's trade surplus, producing goods hosting high-tech in their nature, availability of expert and skilled labor force. But one of the main points in the realization of these factors is the quality of higher education. Higher education has an important role in the formation of qualified labor. And the qualified labor carries the competitiveness firstly of the sector and then of the country up to higher ranks by increasing the performance and productivity of the companies.

Based on Legatum Prosperity Index (2016), Indonesia is rising rapidly and now the position in the top 60 of the Prosperity Index. One of the criteria is education, and Indonesia in the rank of 72th of 149 countries in the world. Among Southeast Asian countries, Indonesia scores highest in Social capital. Thus, the hypothesis that can develop is:

- H4: Education background has a significant effect on competitiveness improvement of SME's

\subsection{Government Regulation}

Government regulation has a vital role in the development of the economic or country, especially in this research is on the development of SME's. Based on the data Bureau Statistics (2017) total SME's in East Java is 12.1 million and 1.3 million unit of the total ready to enter the global market. It means that just 10 percent of SME's has a good competitive advantage. Thus, the next responsibility is back to Government how to make them improve the position or performance through government policy and regulation. In these arguments, the hypothesis that can develop is:

- H5: Government regulation has a significant effect on competitiveness improvement ofSME's

\subsection{Conceptual Framework}

The conceptual framework if this research as follows: 


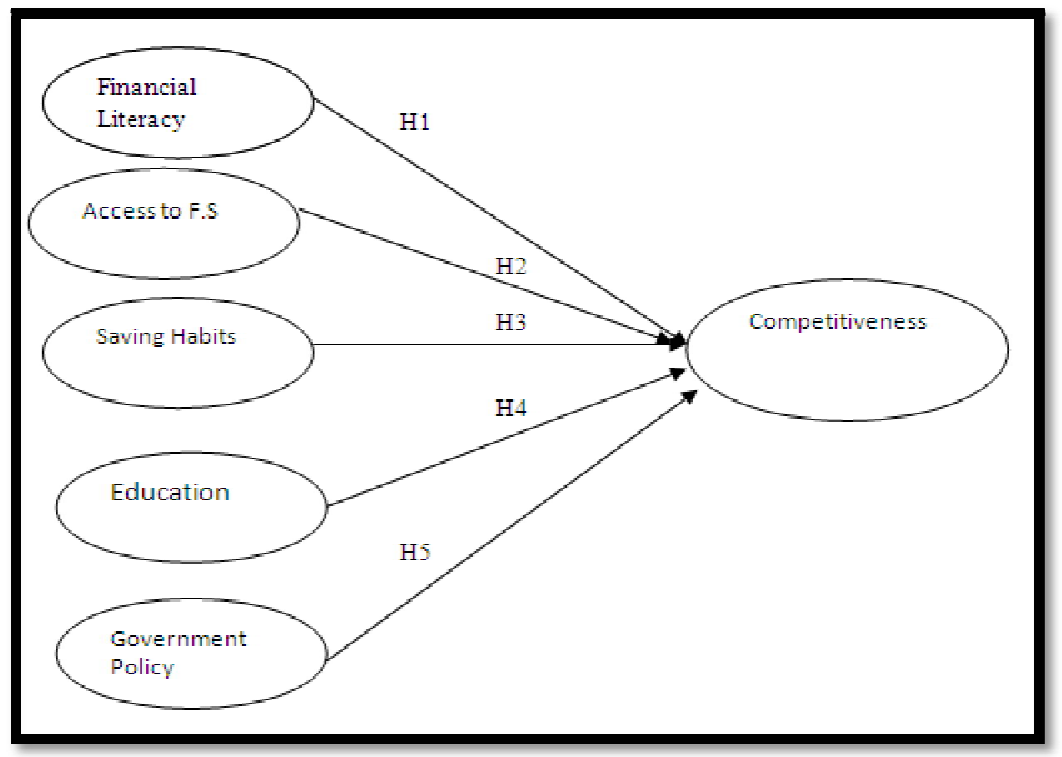

Figure 1: Conceptual Framework

\section{Research Methodology}

This study is a type of research that uses quantitative research method with survey research conducted by distributing questionnaires to the owner's of SME throughout East Java. This study will use regression statistics tools, SPSS 24 by considering several control variables. The variable in this research consists of the dependent variable and the independent variable, as follows:

\subsection{As Dependent Variable ( $\mathrm{Y})$ Is Competitiveness (COMP)}

Aas independent variable (X) is financial literacy (FL), access to financial services (BA), saving habits (SH), education background (EDC), and government regulation(GOV).

\subsection{Population and Sampling Technique}

As the population in this research is the SME's in East Java Province. Based on the data from Statistic Bureau(BPS, 2017), 12.1 million units, consisting of $95 \%$ as Small enterprises and $5 \%$ as Medium enterprises. From those population, the sample that will be used is 204 unit SME's. The total based on Slovin (Sevilla, Consuelo G, Jesus A. Ochave, Twila G. Punsalan, Bella P. Regala\& Gabriel G. Uriarte, 2007: 182).

$$
\begin{gathered}
n=\frac{N}{1+N . e^{2}}=\frac{12.100 .0000}{1+12.100 .000 \times(7 \%)^{2}}=204 \\
\begin{array}{l}
\mathrm{N}=\text { population } \\
\mathrm{n}=\text { sample }
\end{array} \\
\mathrm{e}=(\text { error tolerance })
\end{gathered}
$$

Technique sampling that used is purposive sampling to make easier for data collection. The questionnaire will be distributed to SME's using direct mail. For East Java Province consist of 34 Regencies.

\subsection{Operational Definition}

\subsubsection{Financial Literacy (FL)}

Financial literacy is the possession of the set of skills and knowledge that allows an individual to make informed and effective decisions with all of their financial resources. Financial literacy in this research consists of knowledge of personal financial management, information about financial product and service, operational knowledge.

\subsubsection{Access to Financial Services (BA)}

Access to financial services is access for SME's to use financial product and services such as the bank, insurance, credit cards, investment.

\subsubsection{Saving Habits ( $\mathrm{SH}$ )}

Saving habits are the behavior of the owners of SME's on saving their resources. It can be to the bank, financial market, or stock market. 


\subsubsection{Education Background (EDC)}

Education background is the level of education and experience of the owner of SME's that can be classified to high school, Undergraduate, Graduate program.

\subsubsection{Government regulation (GOV)}

Government regulation that encourages SME's to improve their program or business, through the incentive or stimulus that gave to them. For example lower or special bank rate for SME's,

\subsubsection{Competitiveness (COMP)}

Competitiveness is the ability of an economy to compete fairly and successfully in the markets for internationally traded goods and services that allow for rising standards of living over time. The competitiveness of the SME's in this research is the ability of SME's to compete in the market both local and global market.

Based on all the arguments above, the questionnaires will be as follows :

\begin{tabular}{|c|c|c|c|}
\hline No. & Variable & Indicator & Variable Measurement \\
\hline 1 & $\begin{array}{l}\text { Respondent } \\
\text { Overview }\end{array}$ & $\begin{array}{l}\text { Name, gender, education background, position, type of } \\
\text { business, capital scale }\end{array}$ & Dummy \\
\hline 2 & $\begin{array}{l}\text { Financial Literacy } \\
\quad \text { (FL) }\end{array}$ & $\begin{array}{l}\text { knowledge about financial literacy } \\
\text { A contribution of financial literacy } \\
\text { Training about financial literacy } \\
\text { Information about financial literacy } \\
\text { Skill ability } \\
\text { Understanding financial product and service } \\
\begin{array}{l}\text { Availability of standard or curriculum about SME's } \\
\text { development }\end{array}\end{array}$ & Likert Scale \\
\hline 3 & $\begin{array}{l}\text { Access to Financial } \\
\text { Service (BA) }\end{array}$ & $\begin{array}{l}\text { Documents requirements for open bank account } \\
\text { Easiness for bank access } \\
\text { Capital facilities } \\
\text { Availability of incentive } \\
\text { Availability of the tools or facility suchas EDC } \\
\text { Availability of the facilities for payment activities }\end{array}$ & Likert Scale \\
\hline 4 & Saving Habits (SH) & $\begin{array}{l}\text { Bank as the place to saving money } \\
\text { Bank Saving because the interest is high } \\
\text { Saving when has a balance of the operational cash } \\
\text { Saving to buy jewelry } \\
\text { Saving to buy property or fixed assets } \\
\text { Saving to a stock market } \\
\text { Saving to financial market }\end{array}$ & Likert Scale \\
\hline 5 & $\begin{array}{l}\text { Education knowledge } \\
\text { (EDC) }\end{array}$ & $\begin{array}{l}\text { Hold a formal education } \\
\text { Hold a non-formal education } \\
\text { Joint training and workshop } \\
\text { Join FGD } \\
\text { Job experience }\end{array}$ & Likert Scale \\
\hline 6 & $\begin{array}{c}\text { Government } \\
\text { Regulation (GOV) }\end{array}$ & $\begin{array}{l}\text { Rules of easy doing business } \\
\text { Mentoring } \\
\text { Incentive or stimulus } \\
\text { Open exhibition } \\
\text { Monitoring }\end{array}$ & Likert Scale \\
\hline 7 & $\begin{array}{l}\text { Competitiveness } \\
\text { (COMP) }\end{array}$ & $\begin{array}{l}\text { Achievement of the goals } \\
\text { Sales volume trend } \\
\text { Market area expanded } \\
\text { Competitive with global product }\end{array}$ & Likert Scale \\
\hline
\end{tabular}

Table 1

\subsection{Technical Analysis}

\subsubsection{The Procedure of Data collection}

The Procedure of data collection conducting through questionnaire distribution to SME's in East Java. The sampling that conducted chooses 10 Regencies out of 34 Regencies. Every Regency we choose 20 - 25 SME's, so total questionnaire is $205 \mathrm{SME}$ 's to fill in the questionnaire that the researcher distribute.

The steps are as follows : 
- Determine the object of a survey.

- Determine the total sample that will choose.

- Prepare the questionnaire.

- Conduct a pretest of thequestionnaire

- Decide the time frame for conducting the survey

- The Procedure of Data Analysis

Based on data collected the next steps is doing analysis and interpretation of the result as follows:

- Entry data, prepare a tabulation of the questionnaire

- Conduct validity test andreliability test

- Validity test conducted to measures the validity and reliability of the instrument.This as the particular point of the questionnaire that valid and reliable.Valid questionnaire if the statement or the answerable to describe the indicator measurement of the questionnaire. The questionnaire will be called reliable when the answer of the respondent consistent or stable.

Validity test conducted with makes a correlation the value of the respondent answer with the total value of the answer. The significant value of the variable (is P<alfa 5\%), thus we called that the variable is valid.Reliability test with measure coefficient value. If alpha Cronbach $\geq 0,7$, thus the variable stated reliable. The formula alpha Cronbach:

$\alpha=(\mathrm{k} / \mathrm{k}-1)\left(1-\sum \mathrm{ki}=1 \sigma 2 \mathrm{yi} / \sigma 2 \mathrm{x}\right)$

...where: $\mathrm{kk}$ refers to the number of scale items $\sigma 2$ yioyi2 refers to the variance associated with item $\mathrm{i}$

$\sigma 2 \times \sigma \times 2$ refers to the variance associated with the observed total scores

Conduct the analysis use Regression Analysis, The formula :

$\mathrm{C}=\alpha+\beta_{1} \mathrm{FL}+\beta_{2} \mathrm{AFS}+\beta_{3} \mathrm{SH}+\beta_{4} \mathrm{Ed}+\beta_{5} \mathrm{G}+\varepsilon ;$

where :

$\mathrm{C}:$ competitiveness

FL : Financial Literacy

AFS : Access to Financial services

$\mathrm{SH}$ : Saving Habits

Ed : Education

G : Government Policy

The next step is to conduct a regression test that consists of :

- F test is the test of simultaneous parameter significantly

- $\mathrm{R}^{2}$ test (Coefficient determination)

- $\mathrm{t}$-test is the test for individual parameter significantly with criteria:

- If $t \geq(0.05)$, mean independent variable as an individual has a significant effect on the dependent variable.

- If $\mathrm{t} \leq(0.05)$, mean independent variable as an individual has no significant effect on the dependent variable.

\section{Result}

This study was conducted in East Java Province, that consist of 34 regencies with total population on SME's more than 12.1 million units. As a sample the researcher divide into 205 respondents (SME's) that spreading into East, West, South, North and Surabaya Center, that includes Surabaya, Mojokerto, Malang, Blitar, Bojonegoro, Tuban, Gresik, Lamongan, Bangkalan, Probolinggo, Jember, and Banyuwangi. These regions represent the dominant of SME's that established in East Java.

The resulting divide into two categories first is the background of respondents that consist of gender, working capital, education background, age and types of business. The study founded that based on gender, the dominant gender is Men $62.4 \%$ and women 37.6\%. That means that the majority of owners of SME's in East Java Province is Men. As we know that men are more confident and brave than women. As shown below:

\begin{tabular}{|c|c|c|c|c|c|}
\hline \multicolumn{6}{|c|}{ Gender } \\
\hline \multirow{3}{*}{ Valid } & Men & 128 & 62,4 & 62,4 & Cumulative Percent \\
\cline { 2 - 6 } & Women & 77 & 37,6 & 37,6 & 62,4 \\
\cline { 2 - 6 } & Total & 205 & 100,0 & 100,0 & 100,0 \\
\hline
\end{tabular}

Based on the working capital, the classification is working capital less than Rp 50 million the results is $35.6 \%$, the working capital more than Rp 50 million until Rp 100 million is $25.9 \%$, the working capital more than Rp 100 million until Rp 500 million is $23.9 \%$, and the working capital more than $\mathrm{Rp} 500$ million is $14.6 \%$. Thus, based on this result we know that the most dominant working capital is medium size. As shown below: 


\begin{tabular}{|c|c|c|c|c|c|}
\hline \multicolumn{2}{|c|}{ Working Capital } & Frequency & Percent & Valid Percent & Cumulative Percent \\
\hline Valid & Less than Rp 50 million & 73 & 35,6 & 35,6 & 35,6 \\
\cline { 2 - 6 } & $\begin{array}{c}\text { Rp 50 million to 100 } \\
\text { million }\end{array}$ & 53 & 25,9 & 25,9 & 61,5 \\
\cline { 2 - 6 } & $\begin{array}{c}\text { Rp 100 million to } \\
\text { 500millon }\end{array}$ & 49 & 23,9 & 23,9 & 85,4 \\
\cline { 2 - 6 } & $\begin{array}{c}\text { More than Rp 500 } \\
\text { million }\end{array}$ & 30 & 14,6 & 14,6 & 100,0 \\
\cline { 2 - 6 } & Total & 205 & 100,0 & 100,0 & \\
\hline
\end{tabular}

Table 3: Working Capital

The next analysis is the education background of SME's owners. The education background we classify into two categories, graduate and graduate. Based on the result, the graduate background is $26.8 \%$ and non graduate is $73.2 \%$. that means that the educational background of the owners mostly non graduate that consist of senior high school, and diploma. For graduate background consist of from higher education, such as graduate and master degree, that's why the total is lower than non graduate background. As shown below:

\begin{tabular}{|c|c|c|c|c|c|}
\hline \multicolumn{2}{|c|}{} & Frequency & Percent & $\begin{array}{c}\text { Valid } \\
\text { Percent }\end{array}$ & $\begin{array}{c}\text { Cumulative } \\
\text { Percent }\end{array}$ \\
\hline Valid & $\begin{array}{c}\text { non } \\
\text { graduate }\end{array}$ & 150 & 73,2 & 73,2 & 73,2 \\
\cline { 2 - 6 } & graduate & 55 & 26,8 & 26,8 & 100,0 \\
\cline { 2 - 6 } & Total & 205 & 100,0 & 100,0 & \\
\hline
\end{tabular}

Table 4: Education

Therefore, we will see the result based on the age of the owners, the dominant age is between 41 years to 50 years with $42.9 \%$, the second is the age between 51 to 60 years old with $33.7 \%$, and the age below 40 years is $14.1 \%$ and rest is $9.3 \%$ as the result of the age of more than 60 years old. As seen below:

\begin{tabular}{|c|c|c|c|c|c|}
\hline \multicolumn{2}{|c|}{} & Frequency & Percent & $\begin{array}{c}\text { Valid } \\
\text { Percent }\end{array}$ & $\begin{array}{c}\text { Cumulative } \\
\text { Percent }\end{array}$ \\
\hline \multirow{3}{*}{ Valid } & Up till 40 years old & 29 & 14,1 & 14,1 & 14,1 \\
\cline { 2 - 6 } & 41 to 50 years old & 88 & 42,9 & 42,9 & 57,1 \\
\cline { 2 - 6 } & 51 to 60 years old & 69 & 33,7 & 33,7 & 90,7 \\
\cline { 2 - 6 } & $\begin{array}{c}\text { More than 60 years } \\
\text { old }\end{array}$ & 19 & 9,3 & 9,3 & 100,0 \\
\cline { 2 - 6 } & Total & 205 & 100,0 & 100,0 & \\
\hline
\end{tabular}

Table 5: Age of the Owners

Based on types of business, in this study classified into four, that is food and beverage, craft, trading such as general trading especially for consumer goods, and others such as construction. The result indicates that $7.8 \%$ is food and beverage, $5.9 \%$ is the craft, $42.3 \%$ is trading and 43.9 is others. As seen below:

\begin{tabular}{|c|c|c|c|c|c|}
\hline \multicolumn{2}{|c|}{} & Frequency & Percent & $\begin{array}{c}\text { Valid } \\
\text { Percent }\end{array}$ & $\begin{array}{c}\text { Cumulative } \\
\text { Percent }\end{array}$ \\
\hline Valid & Food\& Beverage & 16 & 7,8 & 7,8 & 7,8 \\
\cline { 2 - 6 } & Craft & 12 & 5,9 & 5,9 & 13,7 \\
\cline { 2 - 6 } & Trading & 87 & 42,4 & 42,4 & 56,1 \\
\cline { 2 - 6 } & Others & 90 & 43,9 & 43,9 & 100,0 \\
\cline { 2 - 6 } & Total & 205 & 100,0 & 100,0 & \\
\hline
\end{tabular}

Table 6: Types of Business

If we look in detail about the relationship between working capital and types of business, the most dominant types of business for the smallest working capital is food and beverage $68.8 \%$. The smallest number of types of business for the largest working capital is food and beverage $6.3 \%$. As seen below: 


\begin{tabular}{|c|c|c|c|c|c|c|}
\hline \multirow{2}{*}{\multicolumn{3}{|c|}{ Working Capital }} & \multicolumn{4}{|c|}{ Types of Business } \\
\hline & & & Food\& Beverage & Craft & Trading & Others \\
\hline \multirow{8}{*}{ Valid } & \multirow{2}{*}{$\begin{array}{l}\text { Less than } 50 \\
\text { million }\end{array}$} & Count & 11 & 4 & 28 & 30 \\
\hline & & \% within typesofbuss. & $68,8 \%$ & $33,3 \%$ & $32,2 \%$ & $33,3 \%$ \\
\hline & \multirow{2}{*}{$\begin{array}{l}50 \text { million to } \\
100 \text { million }\end{array}$} & Count & 3 & 3 & 25 & 22 \\
\hline & & $\%$ within types of buss. & $18,8 \%$ & $25,0 \%$ & $28,7 \%$ & $24,4 \%$ \\
\hline & \multirow{2}{*}{$\begin{array}{c}100 \text { million to } \\
500 \text { million }\end{array}$} & Count & 1 & 2 & 20 & 26 \\
\hline & & $\%$ within type of buss. & $6,3 \%$ & $16,7 \%$ & $23,0 \%$ & $28,9 \%$ \\
\hline & \multirow{2}{*}{$\begin{array}{l}\text { More than } 500 \\
\text { million }\end{array}$} & Count & 1 & 3 & 14 & 12 \\
\hline & & $\%$ within types of buss. & $6,3 \%$ & $25,0 \%$ & $16,1 \%$ & $13,3 \%$ \\
\hline & \multirow[t]{2}{*}{ Total } & Count & 16 & 12 & 87 & 90 \\
\hline & & \% within Jenis Usaha & $100,0 \%$ & $100,0 \%$ & $100,0 \%$ & $100,0 \%$ \\
\hline
\end{tabular}

Table 7: Working Capital Dan Types of Business

Based on the result we can summarize that the data is valid, as seen below:

The following is an overview of the profile of SME respondents in the East Java province including gender, capital, education, age and type of business.

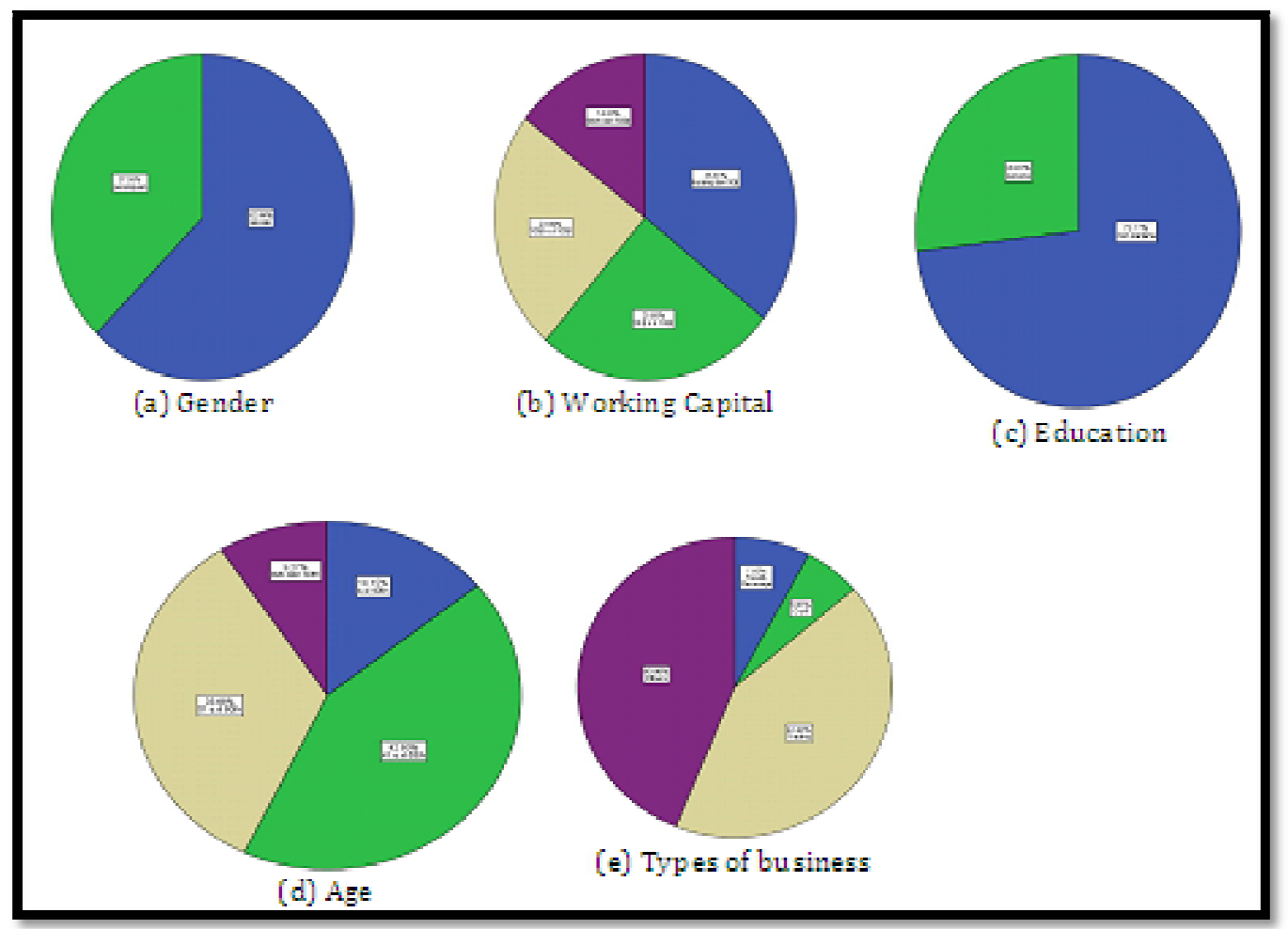

Figure 2: Statistics-Descriptive Of Respondent's Profile

Based on Figure 2 (a), it can be seen that the majority of SME leaders are male (i.e: 82.4\%). Whereas the female SME leader was $37.8 \%$. The second respondent's profile is working capital, as in Figure 1 (b) it can be seen that the majority of SME's working capital is less than 50 million (as much as 35.6\%). While the SME's with working capital of 50 million to 100 million and 100 million to 500 million has the same percentage which is around $25 \%$. SME's working capital of more than 500 million has a percentage of $14.6 \%$. Education is the profile of the third respondent where $73.2 \%$ of SME's education background is non-graduate and $26.8 \%$ are undergraduate. This percentage shows that running a business does not require higher education. The respondents' empathy profile is an age where based on Figure 1 (d) it can be seen that the majority of the age of SME leaders are 41 to 50 years $(42.9 \%)$ and 61 to 60 years $(33.7 \%)$. The profile of the last respondent is the type of business. Based on Figure 1 (e), it can be seen that the majority of SME's business types are other (by $43.9 \%$ ) and trading (by $42.4 \%$ ). While the types of food and beverage and craft businesses are $7.8 \%$ and $5.9 \%$ respectively.

\section{Discussion}

After knowing the respondent's profile, this study will review the relationship of financial literacy, Bank Access, Saving Habit, Education, and Government Regulation to Competitiveness. The seven variables are measured using several indicators, so they need to be tested for validity and reliability. The validity test used is corrected item-total correlation which can be charged as follows: 


\begin{tabular}{|c|c|c|c|c|c|c|}
\hline & $\begin{array}{c}\text { Financial } \\
\text { Literacy }\end{array}$ & $\begin{array}{c}\text { Bank } \\
\text { Access }\end{array}$ & $\begin{array}{c}\text { Saving } \\
\text { Habit }\end{array}$ & Education & $\begin{array}{c}\text { Government } \\
\text { Regulation }\end{array}$ & Competitiveness \\
\hline 1st indicator & 0.387 & 0.231 & 0.192 & -0.217 & 0.204 & 0.382 \\
\hline 2nd indicator & 0.418 & 0.239 & 0.053 & -0.065 & 0.429 & 0.467 \\
\hline 3rd indicator & 0.449 & 0.453 & 0.294 & 0.505 & 0.364 & 0.756 \\
\hline 4th indicator & 0.413 & 0.255 & 0.089 & 0.502 & -0.063 & 0.597 \\
\hline 5th indicator & 0.002 & 0.215 & 0.075 & 0.626 & 0.251 & 0.477 \\
\hline 6th indicator & 0.242 & 0.322 & 0.055 & 0.490 & 0.230 & 0.172 \\
\hline 7th indicator & 0.318 & 0.361 & -0.009 & 0.426 & 0.100 & \\
\hline 8th indicator & 0.414 & 0.265 & -0.103 & & 0.212 & \\
\hline 9th indicator & 0.066 & 0.165 & -0.076 & & 0.314 & \\
\hline 10th & -0.007 & & & & 0.089 & \\
indicator & & & & & & \\
\hline
\end{tabular}

Table 8: Validity Test for Seven Variables

Financial literacy is formed by 10 indicators or question items. Based on Table 7, it can be seen that indicators 5, 9, and 10 are less than R tables with free degrees $n-1$ (205 - $1=204)$ of 0.137 . So, indicators 5, 9, and 10 are invalidly used to form financial literacy variables. Therefore, all three invalid indicators are issued in the financial literacy variable and tested again. The test results returned without using indicators 5, 9, and 10 obtained valid results, then the reliability test can be done using a valid indicator. Based on Table 7, it can be seen that all indicators forming the Bank Access variable have been greater than the R table (amounting to 0.137 ).

The variable Saving Habit is formed using 9 indicators where there are indicators that have corrected item-total correlation negative. However, compared to the $\mathrm{R}$ table is the absolute value of the corrected item-total correlation. Based on these principles, valid indicators have only two, namely indicator 1 and indicator 3 . This is contrary to the minimum indicators that can be used in testing validity, namely a minimum indicator of variable formation of at least 3 indicators.So that in this study indicators 7, 8, and 9 will be issued which produce valid indicators 1 to 6 .

The next variable is an education background that formed using 7 indicators, where indicator 2 is invalid. Based on the validity test without including indicator 2 , the results of all indicators are valid. There are 10 indicators that form the variable Government Regulation. Based on Table 7, it can be seen that indicators 4, 7, and 10 are invalid. The results of the repeat validity test without the three indicators produced are still invalid, namely indicator 6 . The results of the repeat validity test without the four indicators produce an invalid indicator 5 . The results of the repeat validity test without the five indicators produce all valid indicators. The last variable is competitiveness which is formed using 6 indicators.

Based on Table 7, it can be seen that the six indicators forming the competitiveness variable are valid. Based on valid indicators, reliability testing using Cronbach's Alpha can be labeled as follows:

\begin{tabular}{|c|c|c|}
\hline Variable & Indicator & Cronbach's Alpha \\
\hline Financial Literacy & FL1, FL2, FL3, FL4, FL6, FL7, FL8 & 0.707 \\
\hline Bank Access & BA1 to BA9 & 0.587 \\
\hline Saving Habit & SH1 to SH6 & 0.555 \\
\hline Education & ED1, ED3 to ED7 & 0.666 \\
\hline Government Regulation & GOV1, GOV2, GOV3, GOV8, GOV9 & 0.653 \\
\hline Competitiveness & COMP1 to COMP6 & 0.729 \\
\hline
\end{tabular}

Table 9: Reliability Test

Based on Table 8, the value of Cronbach's Alpha which exceeds 0.7 is the financial literacy and competitiveness variable. So that both variables with their forming indicators can be said to be reliable. While the bank access, saving habit, education, and government regulation variables have a Cronbach's Alpha value of more than 0.5 , so it can be said to be quite reliable. Then the seven variables can be formed using the average of indicators that are valid and reliable.

The relationship of financial literacy, Bank Access, Saving Habit, Education, and Government Regulation to Competitiveness can be analyzed using multiple regression analysis. Multiple regression analysis can be done if there is no multicollinearity between the independent variables. The test can be seen from the VIF value that can be labeled as follows: 


\begin{tabular}{|c|c|}
\hline Variable & VIF \\
\hline Financial Literacy & 1.407 \\
\hline Bank Access & 1.221 \\
\hline Saving Habit & 1.010 \\
\hline Education & 1.692 \\
\hline Government Regulation & 1.199 \\
\hline
\end{tabular}

Table 10: VIF Multicollinearity Test

Based on Table 9, it can be seen that the VIF value of each independent variable does not exceed 10 so that multicollinearity does not occur.

The multiple regression analysis carried out in this study uses a stepwise method where variables that are significant to competitiveness are selected. The following is the result of multiple regression analysis with the stepwise method.

\begin{tabular}{|c|c|c|c|c|c|c|}
\hline \multirow{2}{*}{\multicolumn{2}{|c|}{ Model }} & \multicolumn{2}{|c|}{ Unstandardized Coefficients } & \multirow{2}{*}{$\frac{\text { Standardized Coefficients }}{\text { Beta }}$} & \multirow{2}{*}{$\mathbf{t}$} & \multirow{2}{*}{ Sig. } \\
\hline & & $\mathrm{B}$ & Std. Error & & & \\
\hline \multirow{2}{*}{1} & (Constant) & 2.228 & 0.277 & & 8.032 & 0.000 \\
\hline & BACC & 0.319 & 0.087 & 0.250 & 3.674 & 0.000 \\
\hline \multirow{3}{*}{2} & (Constant) & 1.876 & 0.306 & & 6.121 & 0.000 \\
\hline & BACC & 0.248 & 0.090 & 0.194 & 2.754 & 0.006 \\
\hline & EDC & 0.174 & 0.068 & 0.180 & 2.557 & 0.011 \\
\hline \multirow{4}{*}{3} & (Constant) & 1.459 & 0.370 & & 3.941 & 0.000 \\
\hline & BACC & 0.197 & 0.093 & 0.154 & 2.115 & 0.036 \\
\hline & EDC & 0.216 & 0.071 & 0.224 & 3.049 & 0.003 \\
\hline & GOV & 0.142 & 0.072 & 0.141 & 1.978 & 0.049 \\
\hline
\end{tabular}

Table 11: Multiple Regression Analysis- Stepwise Method

Based on Table 10, it can be seen that the stepwise method optimization has 3 steps. The first step of the most significant variable is bank access. Then the second step of the significant variable is education and the third is government regulation. So that bank access, education, and government regulation are variables that have a significant effect on competitiveness. The regression equation can be written as follows:

Competitiveness $=1.459+0.197$ bank access +0.216 education +0.142 government regulation

The equation above states that the effect of education on competitiveness is greater than bank access and government regulation on competitiveness. In addition, the three independent variables have a positive correlation with competitiveness. So that the higher the bank access, education, and government regulation, the higher competitiveness.

In multiple regression analysis, the classical assumption is that residuals are normally distributed, the residuals do not occur autocorrelation, and homoscedasticity. The first assumption (residual normally distributed) using KolmogorovSmirnov and Shapiro-Wilk obtained p-values of 0.004 and 0.001 . The P-value is less than 0.05 so it can be said that the residual is not normally distributed. This is because the value of the competitiveness variable is obtained from the average results so that the data is worth 1 to 5 . The second assumption is that there is no autocorrelation using the Durbin Watson test. The Durbin Watson value is 1,361 where it approaches the number 2 so that it can be said that there is no autocorrelation. The last assumption is homoscedasticity using a glace test where the absolute value of the residuals will be regressed with a significant independent variable. The results of the glacier test indicate that the variable bank access and government regulation are not significant ( $p$-value 0.464 and 0.179 ). While the education variable is significant with a $\mathrm{p}$-value of 0.002 . So it can be concluded that the residuals have met the homoscedastic assumptions.

\section{Conclusions}

This research analyzes the effects of financial inclusions that consist of financial literacy, access to financial services (bank access), saving habits, education, government regulation has a significant effect toward competitiveness improvement of SME'sin East Java Province. Basedon the validity and reliability test, all variables are valid and reliable(see table 7 and table 8). Basedon multiple regression analysis - under stepwise method, we found that bank access has the most significant effect that other variables. The second step of the significant variable is education background and the third step is government regulation (see table 10). That means bank access, education and government regulation have a significant effect on competitiveness improvement of SME'E in East Java Province.

\section{Recommendation}

The recommendation from the researcher can be stated as follows:

- To the SME's owners, they must improve their knowledge through improving educational background to increase their competitiveness.

- To thebanking institution, they shall improve their policy and regulation for giving easiness to the SME'son increasing their working capital.

- To the government, shall improve their policyorregulation that related to the improvement ofthe competitiveness of SME's. 


\section{References}

i. Bank Indonesia (2004), Booklet of Financial Inclusion.

ii. Beck, T., Buyukkaraback, B., Rioja, F.K., Valev, N.T., 2012. Who gets the credit? And does it matter? Household vs. firm lending across countries. The B.E. Journal of Macroeconomics 12.

iii. Beck, T., Levine, R., \&Levkov, A. (2007a). Bank regulation and income distribution: Evidence from branch deregulation. Brown University and the Watson Institute for International Studies.

iv. Beck, T., Levine, R., \& Levkov, A. (2007b).Big bad banks? The impact of US branch deregulation on income distribution (No. w13299). National Bureau of Economic Research.

v. Chakravarty, S. R., \& Pal, R. (2013). Financial inclusion in India: An axiomatic approach. Journal of Policy Modeling, 35(5), 813-837

vi. Cole, S., Sampson, T., Zia, B., 2011. Prices or knowledge? What drives demand for financial services in emerging markets? Journal of Finance LXVI (6).

vii. Demirgu-Kunt.,Klapper (2012), Measuring Financial Inclusion: The Global Findex Database, world bank, Policy Research Working Paper, No. 6025

viii. Encarta Dictionary (2010). Micro Soft Encarta Dictionary, Microsoft Corporation

ix. Goland, Tony, et.al., (2010), Global Financial Inclusion, Mc.Kinsey and Company, Washington DC

x. Gwalani, H., \&Parkhi, S. (2014). Financial Inclusion-Building a Success Model in the Indian Context. Procedia-Social and Behavioral Sciences, 133, 372-378.

xi. Ghozali, Imam (2014), Ekonometrika, Teori, Konsep dan Aplikasidengan SPSS 22, Badan Penerbit Universitas Diponegoro Semarang

xii. Hilal YildirirKeser (2015), Effects of Higher Education on Global Competitiveness: Review in Relation to Europen Countries and Middle East Countries, JEL: F63

xiii. Kumar, N. (2013). Financial inclusion and its determinants: evidence from India. Journal of Financial Economic Policy, 5(1),4-19.

xiv. Levine, R. (2003). More on finance and growth: more finance, more growth?.Review-Federal Reserve Bank Of Saint Louis, 85(4),31-46.

xv. Porter E. Michael, (1985), Competitive Advantage Creating and Sustaining Superior Performance, NY Press

xvi. Porter E. Michael, (1990), Competitive Advantage of Nation, Mcmillan

xvii. Rao, N., \& Bhatnagar, M. H. (2012). Financial Inclusion: Issues and Prospects. Pacific Business Review International, $5(3), 84-96$

xviii. Rimmande, et, al., (2015). The Effect of Saving and Saving habits on Entrepreneurship Development, European Journal of Business and Management. Vol. 7.No. 23

xix. Sassi, S., Gasmi, A. 2014. The effect of enterprise and household credit on economic growth: New evidence from European Union countries. Journal of Macroeconomics 39, 226-231.

xx. Slovin, et., al., (2007) how to determine sample size

xxi. Xhavit Ajvaz Islami, et.al., (2015) The Effect of Industrial and Internal Factors to the Firm's Performance: Jurnal of AUDB, Volume 14, No.5, 2018. 